\title{
Penggunaan Metode Pembelajaran Teams Games Tournament (TGT) untuk Meningkatkan Aktivitas dan Prestasi Balajar
}

\author{
Erwinta Noviana \\ Program Studi Pendidikan Guru Sekolah Dasar \\ Kampus V UAD Jalan Ki Ageng Pemanahan No. I9 Sorosutan Yogyakarta 55I64 \\ Surat-e: erwintanovi@gmail.com
}

Erwinta Noviana ${ }^{1}$ dan Okimustava

Program Studi Pendidikan Fisika²

Kampus 3 UAD Jalan Prof. Dr. Soepomo, S.H. Janturan Yogyakarta 55164

Surat-e: omustava@yahoo.com

\begin{abstract}
Penelitaian ini dilatar belakangi proses pembelajaran yang kurang menarik bagi siswa, hanya berpusat pada guru, tidak adanya keaktifan siswa. Penelitian ini bertujuan untuk mengetahui peningkatan aktivitas dan prestasi belajar mata pelajaran IPA dengan menggunakan metode pembelajaran Teams Games Tournament (TGT). Subyek dalam penelitian ini adalah siswa kelas IV SD Negeri Guwo Tahun Ajaran 2015/2016. Teknik yang digunakan untuk mengumpulkan data meliputi observasi, tes dan dokumentasi. Analisis data menggunakan analisis data kuantitatif yang didukung dengan analisis data kualitatif. Penelitian ini merupakan penelitian tindakan kelas yang terdiri dari dua siklus, pada tahap siklus mencakup kegiatan: perencanaan, pelaksanaan, pengamatan dan refleksi. Kriteria keberhasilan dalam penelitian dilihat dari peningkatan ktivitas dan prestasi belajar siswa. Berdasarkan hasil penelitian diperoleh penggunaan metode pembelajaran Teams Games Tournament (TGT) dapat meningkatkan aktivitas dan prestasi belajar siswa.
\end{abstract}

Inactive student, teacher centered, and less interesting teach has leaded to this research to be happened. Teams Games Tournament (TGT) model is applied as the goal of the research which to observe how much activity and affective result can be reach. Observation, test, and documentation are the main step in this research. Quantitative data analysis applied besides qualitative data analysis. There are two cycles in this research, each cycle consist of planning, doing, seeing, and reflection. The increase in student activity and achievement are main goals in this research. According to the result this model can be used to increase student activity and achievement.

Kata kunci: Pembelajaran teams games tournament, aktivitas belajar, prestasi belajar

\section{Pendahuluan}

Aktivitas belajar peserta didik sangat diutamakan, karena aktivitas belajar merupakan salah satu penunjang dalam meningkatkan proses pembelajaran yang ada di kelas [I]. Prestasi merupakan "tingkat kemanusiaan yang dimiliki siswa dalam menerima, menolak dan menilai informasi-informasi yang diperoleh dalam proses belajar mengajar" [2]. Berdasarkan daftar nilai IPA ujian tengah semester dan ujian akhir semester pertama, menunjukan rata-rata nilai kelas masih di bawah KKM.

Dari hasil observasi diperoleh pembelajaran didominasi oleh penggunaan metode ceramah, tanya jawab dan kegiatan lebih berpusat pada guru. Aktivitas siswa dapat di katakan hanya mendengarkan penjelasan guru, mencatat hal-hal yang dianggap penting saja, dan menjawab pertanyaan jika ditunjuk, ada pula beberapa siswa yang mengantuk, bermalas-malasan dan melakukan kegiatan yang tidak ada hubungannya dengan pelajaran. 
Metode pembelajaran Teams Games Tournament (TGT) memungkinkan peserta didik berperan aktif dalam kegiatan pembelajaran serta mampu bekerjasama dalam kelompok. Dari hasil penelitian yang dilakukan oleh [3] menunjukan bahwa metode pembelajaran cooperative tipe Teams Games Tournament (TGT) mampu meningkatkan motivasi dan prestasi belajar pada mata pelajaran IPS. Dengan metode pembelajaran ini diharapkan aktivitas dan prestasi belajar siswa menjadi lebih meningkat

\section{Kajian Pustaka}

\section{Cooperative tipe Teams Games Tournamen (TGT)}

Teams Games Tournament merupakan salah satu metode pembelajaran cooperative yang dikembangkan oleh slavin untuk membantu siswa mereview dan menguasai materi pelajaran". Slavin menemukan bahwa TGT berhasil meningkatkan skill-skill dasar, pencapaian, interaksi positif antarsiswa, harga diri dan sikap penerimaan pada siswa-siswa lain yang berbeda $[4]$.

Terdapat lima komponen utama dalam pembelajaran Cooperative tipe Teams Games Tournament (TGT) dan alurnya ditunjukkan gambar I [5].

a. Penyajian Kelas (Class Pressentation)

Penyajian kelas dalam pembelajaran cooperative tipe Teams Games Toumament (TGT) tidak berbeda dengan pengajaran biasa atau pengajaran klasikal oleh guru, hanya pengajaran lebih difokuskan pada materi yang sedang dibahas saja.Ketika penyajian kelas berlangsung mereka sudah berada dalam kelompoknya.

b. Kelompok (Teams)

Kelompok disusun dengan beranggotakan 4-5 orang yang mewakili pencampuran dari berbagai keragaman dalam kelas seperti kemampuan akademik, jenis kelamin, rasa tau etnik. Fungsi utama mereka dikelompokkan adalah anggotaanggota kelompok saling meyakinkan bahwa mereka dapat bekerja sama dalam belajar dan mengerjakan game atau lembar kerja dan lebih khusus lagi untuk menyiapkan semua anggota dalam menghadapi kompetisi.

c. Permainan (Games)

Pertanyaan dalam game disusun dan dirancang dari materi yang relevan dengan materi yang telah disajikan untuk menguji pengetahuan yang diperoleh mewakili masing-masing kelompok. Sebagian besar pertanyaan pada kuis adalah bentuk sederhana.Setiap siswa mengambil sebuah kartu yang diberi nomor dan menjawab pertanyaan yang sesuai dengan nomor pada kartu tersebut. d. Kompetisi/Turnament (Turnaments)

Turnamen adalah susunan beberapa game yang dipetandingkan. Biasanya dilaksanakan pada akhir minggu atau akhir unit pokok bahasan, setelah guru memberikan penyajian kelas dan kelompok mengerjakan lembar kerjanya. Untuk ilustrasi tournament dapat dilihat pada skema di bawah ini.

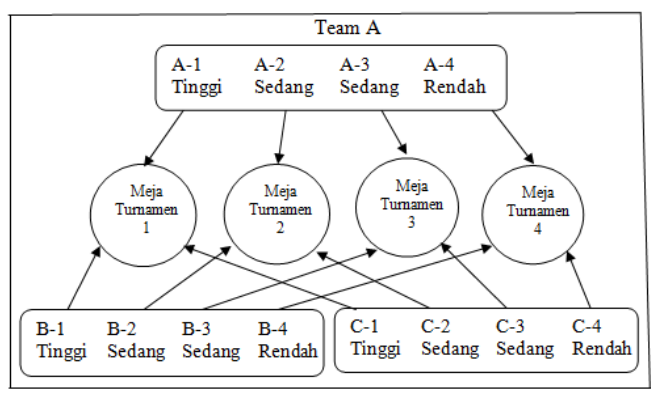

Gambar I. Alur Pemetaan Peserta Turnamen (Slavin, 2005: I68)

\section{Aktivitas Belajar}

Aktivitas belajar salah satu kegiatan yang dilakukan oleh siswa ketika proses pembelajaran sedang berlangsung. Seperti yang dikemukakan oleh [I] bahwa "aktivitas merupakan prinsip atau asas yang sangat penting di dalam interaksi belajar-mengajar".

Proses pembelajaran memiliki aktivitas belajar yang bermacam-macam. Di bawah ini akan diuraikan tentang jenis-jenis aktivitas belajar menurut ahlinya. Adapun jenisjenis aktivitas dalam belajar yang digolongkan oleh Paul B. Diedrich [I] adalah sebagai berikut:

a) Visual activities, yang termasuk di dalamnya misalnya membaca, memperhatikan gambar demonstrasi, percobaan, pekerjaan orang lain.

b) Oral Activities, seperti menyatakan merumuskan,bertanya, memberi saran, berpendapat, diskusi, interupsi.

c) Listening Activities, sebagai contoh mendengarkan:uraian, percakapan, diskusi, musik, pidato.

d) Writing Activities, seperti misalnya menulis cerita,karangan, laporan, menyalin.

e) Drawing Activities, menggambar, membuat grafik, peta,diagram.

f) Motor Activities, yang termasuk di dalamnya antara lain: melakukan percobaan, membuat konstruksi, model, mereparasi, berkebun, beternak.

g) Mental Activities, sebagai contoh misalnya: menanggapi, mengingat, memecahkan soal, menganalisis, mengambil keputusan.

h) Emotional Activities, seperti misalnya, merasa bosan,gugup, melamun, berani, tenang

\section{Prestasi Belajar}


Prestasi belajar merupakan hasil yang dicapai siswa selama mengikuti kegiatan pembelajaran. Seperti yang dikemukakan oleh [6] bahwa "prestasi sebagai tingkat keberhasilan yang dicapai oleh siswa setelah mengikuti suatu kegiatan pembelajaran”.

Faktor yang mempengaruhi prestasi belajar adalah kecerdasan, minat, bakat dan motivasi [7].

\section{Metode Penelitian/Eksperimen}

Jenis penelitian yang akan digunakan dalam penelitian ini adalah penelitian tindakan kelas. Dalam penelitian ini melalui 3 tahap yaitu, (I) merencanakan, (2) melaksanakan, dan (3) merefleksikan tindakan yang sudah dilakukan. Teknik pengambilan data dalam penelitian ini menggunakan teknik tes dan non-tes yang terdiri dari observasi, tes dan dokumentasi. Adapun untuk analisis data menggunakan analisis data kuantitatif yang didukung oleh analisis data kualitatif.

\section{Hasil Penelitian dan Pembahasan}

Hasil yang diperoleh dalam penelitian ini adalah terjadi peningkatan aktivitas dan prestasi belajar siswa. Hasil dari aktivitas belajar siswa pra-penelitian diperoleh rata-rata aktivitas belajar siswa sebesar 25,92\% dengan kategori "Kurang Aktif', meningkat pada siklus I diperoleh ratarata aktivitas belajar siswa sebesar 52,59\% dengan kategori "Cukup Aktif" dan mengalami peningkatan lagi pada siklus II sebesar 65,55\% dengan kategori “Aktif”.

Hasil dari prestasi belajar siswa diperoleh presentase ketuntasan belajar siswa sebelum dilakukan tindakan sebesar 22,22\% dari jumlah keseluruhan siswa dengan kriteria "Kurang". Setelah dilakukan tindakan pada siklus I mengalami peningkatan dan diperoleh presentase ketuntasan belajar siswa sebesar $66,67 \%$ dari jumlah keseluruhan siswa dengan kriteria "Baik". Kemudian mengalami peningkatan pada siklus II dengan diperoleh presentase ketuntasan belajar siswa sebesar 88,89\% dengan kriteria "Baik Sekali" ditunjukkan tabel I.

Tabel I. Rata-rata peningkatan aktivitas belajar siswa kelas IV.

\begin{tabular}{lccc}
\hline \multicolumn{1}{c}{ Keterangan } & $\begin{array}{c}\text { Pra- } \\
\text { tindakan }\end{array}$ & Siklus I & Siklus II \\
\hline Kegiatan Visual & $61,1 \mathrm{I} \%$ & $72,22 \%$ & $87,04 \%$ \\
Kegiatan Lisan & 0 & $33,33 \%$ & $46,29 \%$ \\
Kegiatan Menulis & $68,51 \%$ & $74,07 \%$ & $85,15 \%$ \\
Kegiatan Mental & 0 & $35,18 \%$ & $48,15 \%$ \\
$\begin{array}{l}\text { Kegiatan Emosional } \\
\text { Rata-rata aktivitas }\end{array}$ & 0 & $48,15 \%$ & $61,11 \%$ \\
siswa $(\%) \quad 25,92 \%$ & $52,59 \%$ & $65,55 \%$ \\
\hline
\end{tabular}

\section{Kesimpulan}

Pembelajaran IPA yang telah dilakukan menggunakan metode pembelajaran Teams Games Tournament (TGT) dapat meningkatkan prestasi belajar siswa kelas IV SD Negeri Guwo. Jumlah siswa yang mencapai nilai KKM yang ditentukan oleh sekolah meningkat pada siklus I ke siklus II. Pada siklus I diperoleh presentase siswa yang mencapai ketuntasan sebesar 52,59\% kemudian meningkat pada siklus II sebesar 65,55\%.

\section{Ucapan Terimakasih}

Kami mengucapkan terimakasih kepada SD Guwo yang telah memberikan kesempatan untuk melakukan penelitian ini dan semua pihak yang telah berkontribusi dalam penyelesaian penelitian ini.

\section{Kepustakaan}

[I] Sardiman. 20I I. Interaksi Dan Motivasi Belajar Mengajar. Jakarta : PT Raja Gravindo Persada.

[2] Hamdu \& Agustina. 20II. Pengaruh Motivasi Belajar Siswa Terhadap Pestasi Belajar Ipa Di Sekolah Dasar. Jurnal Penelitian Pendidikan. Vol I2. No I. $<$ http://jurnal.upiedu/file/8Ghullam Hamdu.pdf>. 17 Oktober 2015.

[3] Maisaroh .20I I. Upaya Peningkatan Motivasi dan Prestasi Belajar IPS melalui model pembelajaran kooperatife tipe Teams Games Tournament(TGT).Jurnal unnes. Volume 6, No. 2, $<$ http://journal.unnes.ac.id/nju/index.php/DP/article/view/ 5I09> 3 april 2016.

[4] Huda, M. 2013. Model-Model Pengajaran Dan Pembelajaran Yogyakarta: Pustaka pelajar.

[5] Taniredja., Faridli, Harmianto. 2013.Model-Model Pembelajaran Inovatif dan Efektif. Bandung: Alfabeta.

[6] Dimyati dan Mudjiono.2013.Belajar dan pembelajaran.Jakarta : PT Rineka Cipta.

[7] Widodo dan Widayanti. 2013. "Peningkatan Aktivitas Belajar Dan Hasil Belajar Siswa Dengan Metode Problem Based Learningpada Siswa Kelas VIIA Mts Negeri Donomulyo Kulon Progo Tahun Pelajaran 2012/2013". Jurnal Fisika Indonesia.Vol XVII, No. 49, <http://pdmmipa.ugm.ac.id/ojs/index.php/ifi/article/view/83I> 6 Juni 2016. 